\title{
Investigating the contribution of IL-17A and IL-17F to the host response during Escherichia coli mastitis
}

\author{
Perrine Roussel ${ }^{1,2}$, Patricia Cunha ${ }^{1,2}$, Adeline Porcherie ${ }^{1,2}$, Wolfram Petzl ${ }^{3}$, Florence B Gilbert ${ }^{1,2}$, Céline Riollet ${ }^{1,2}$, \\ Holm Zerbe ${ }^{3}$, Pascal Rainard ${ }^{1,2}$ and Pierre Germon ${ }^{1,2^{*}}$
}

\begin{abstract}
Mastitis remains a major disease of cattle with a strong impact on the dairy industry. There is a growing interest in understanding how cell mediated immunity contributes to the defence of the mammary gland against invading mastitis causing bacteria. Cytokines belonging to the IL-17 family, and the cells that produce them, have been described as important modulators of the innate immunity, in particular that of epithelial cells. We report here that expression of IL-17A and IL-17F genes, encoding two members of the IL-17 family, are induced in udder tissues of cows experimentally infected with Escherichia coli. The impact of IL-17A on the innate response of bovine mammary epithelial cells was investigated using a newly isolated cell line, the PS cell line. We first showed that PS cells, similar to primary bovine mammary epithelial cells, were able to respond to agonists of TLR2 and to LPS, provided CD14 was added to the culture medium. We then showed that secretion of CXCL8 and transcription of innate immunity related-genes by PS cells were increased by IL-17A, in particular when these cells were stimulated with live E. coli bacteria. Together with data from the literature, these results support the hypothesis that IL-17A and IL-17 F could play an important role in mediating of host-pathogen interactions during mastitis.
\end{abstract}

\section{Introduction}

Despite decades of research, mastitis remains a major concern in dairy farming. Mastitis are mainly due to bacterial infections (Gram-positive pathogens such as Staphylococcus aureus and Streptococcus uberis, or Gram-negative pathogens such as Escherichia coli) [1].

Previous studies have allowed the identification of key molecular events that ultimately lead to the recruitment of neutrophils in the mammary gland upon bacterial colonization. When bacteria enter the udder, the host responds by secreting chemokines (such as CXCL8, CCL20) and other immune components such as antimicrobial peptides (LAP-lingual antimicrobial peptide, TAP - tracheal antimicrobial peptide) and proinflammatory cytokines (TNF- $\alpha$, IL-1 $\beta$ ) [2-4]. Production of pro-inflammatory cytokines such as IL-1 $\beta$, IL- 6 and TNF- $\alpha$ and the chemokine CXCL8 have been detected in milk from clinically affected animals and are supposed to contribute to the inflammation observed in mastitis $[2,4]$.

\footnotetext{
* Correspondence: pierre.germon@tours.inra.fr

'INRA, UMR1282, Infectiologie et Santé Publique, F-37380 Nouzilly, France

${ }^{2}$ Université François Rabelais de Tours, UMR1282, Infectiologie et Santé

Publique, F-37000 Tours, France

Full list of author information is available at the end of the article
}

In vivo experiments indicate that the severity of $E$. coli mastitis mainly depends on host factors and that a quick and efficient response is important for an efficient clearance of the bacteria [5]. This process relies heavily on the recruitment of neutrophils during infection: a delay in the recruitment of neutrophils aggravates the infection [6,7]. It is therefore expected that any mechanism that modulates the immune response of the host could participate in the defence against $E$. coli mastitis.

IL-17A and IL-17F are two cytokines that have been described as playing a significant role in the recuitment of neutrophils in other inflammatory diseases. Along with four other structurally related cytokines, IL-17B, IL-17C, IL-17D and IL-17E, they form the IL-17 family [8].

Although expression of IL-17A and IL-17F may be detrimental to the host, in particular in the case of autoimmune diseases, they have been shown to be beneficial to the host to fight against bacterial pathogens such as Citrobacter rodentium, Klebsiella pneumoniae or Escherichia coli $[8,9]$.

Production of IL-17A during S. uberis mastitis was recently demonstrated [10]. Tao and Mallard also reported that IL-17A gene expression was slightly increased 
(approx. 1.5-fold in milk) in somatic cells from S. aureus infected cows [11]. Microarray analyses of MEC stimulated with S. aureus culture supernatant also showed induction of the IL-17A pro-inflammatory pathway [12].

In addition, we recently demonstrated that, in vitro, IL-17A increases the ability of mammary epithelial cells (MEC) to respond to agonists similar to that produced by S. aureus [13]. These cells are thought to play a significant role in the defence against invading pathogens by producing antimicrobial peptides as well as cytokines and chemokines such as CXCL8 and IL-6. Indeed, in vitro grown primary bovine MEC (pbMEC) have been shown to respond to the presence of bacteria, such as E. coli or $S$. aureus, or to different purified bacterial agonists by producing different cytokines, chemokines or antimicrobial peptides [12,14-18].

Based on these data, one could hypothesize that IL-17 cytokines contribute to the innate response of the host during E. coli mastitis; but this remains to be studied.

In the present report, we thus decided to investigate, under controlled conditions, whether expression of genes encoding cytokines of the IL-17 family was induced upon intra-mammary infection of cows by $E$. coli. We then explored how this over-expression of IL-17A gene could translate in terms of defence against the invading pathogen. Using a new cell line, called the PS cell line, which we characterized in details in terms of phenotypic markers and response to bacterial agonists, we analysed the influence of IL-17A on the innate immune response of MEC to infection by $E$. coli.

This report brings a new perspective on the cellular features and molecular parameters involved in the ability of MEC to take part in the udder defence against mastitis.

\section{Materials and methods Ethics statement}

Experimental infection of animals were conducted at the Clinic for Ruminants (Munich, Germany) with the approval of the ethics committee of the regional government of upper Bavaria, Germany (No. 55.2-1-54-2531-108-05).

\section{Experimental infection of cows}

Five healthy German Holstein Frisian first lactation cows in mid lactation (3-6 months after parturition) fulfilling criteria as previously described [19] were inoculated in one quarter with $500 \mathrm{cfu} E$. coli strain 1303. Five heifers that received no treatment served as untreated controls. Only animals without previous diagnosis of clinical or subclinical mastitis and a reported somatic cell count $<50000 / \mathrm{mL}$ were included in the study. Quarter milk samples were collected and tested weekly before the trial to ensure that they contained $<50000$ somatic cells $/ \mathrm{mL}$ and were free of mastitis pathogens. Animals were randomly assigned to both groups and the experiments were carried out between March and December. All E. coli inoculated animals developed clinical mastitis in the affected quarter $12 \mathrm{~h}$ after inoculation as previously described [19]. Animals were slaughtered 24 hours postinoculation (hpi). Liquid nitrogen snap frozen udder samples of lobulo-alveolar tissue $7 \mathrm{~cm}$ dorsal of the milk cistern were obtained immediately after slaughtering. RNA was isolated from approx. $100 \mathrm{mg}$ of frozen udder tissue using Trizol (Invitrogen). The sample was placed in a $2 \mathrm{~mL}$ tube containing $1.4 \mathrm{~mm}$ beads (MP Biomedicals) and one $\mathrm{mL}$ of Trizol was added. Tissue lysis was obtained by shaking the tubes twice in a FastPrep apparatus (MP Biomedicals) for $45 \mathrm{~s}$ at speed 6. The homogenate was further processed as recommended by the manufacturer. RNA quality was checked using an Agilent Bioanalyzer and only samples with a RNA Integrity number above 7 were used. Controls included RNA samples from the uninoculated quarters from inoculated cows as well as samples from quarters of non-inoculated cows.

\section{Isolation and culture of PS cells}

The whole mammary gland was isolated from a Prim'Holstein dairy cow. The cow was killed at the slaughterhouse of the INRA dairy facility as part of a routine killing at the end of its $6^{\text {th }}$ lactation. The cow was killed following the recommended guidelines of the American Veterinary Medical Association ("AMVA Guidelines for the Euthanasia of Animals"): first the cow was euthanized using a penetrating captive bolt and killed by exsanguination by the authorized personnel of the slaughterhouse. The mammary gland was removed and transferred to the laboratory for further processing. Pieces of tissue were dissected in the secretory parenchyma and placed in Hank's Balanced Salt Solution (HBSS, Lonza) containing $200 \mathrm{U} / \mathrm{mL}$ penicillin (SigmaAldrich), $200 \mu \mathrm{g} / \mathrm{mL}$ streptomycin (Sigma-Aldrich), $0.5 \mu \mathrm{g} /$ $\mathrm{mL}$ amphotericin B (Gibco). Tissue fragments of $10 \mathrm{~g}$ were washed with HBSS and minced with surgical scissors. The small tissue cubes were washed and incubated at $37{ }^{\circ} \mathrm{C}$ under slight agitation in $30 \mathrm{~mL}$ HBSS containing $5.5 \mathrm{U} / \mathrm{mL}$ protease from Streptomyces griseus (Sigma-Aldrich). Every $30 \mathrm{~min}$, the dispersed cells were harvested from the mixture by filtration through a $200 \mu \mathrm{m}$ nylon mesh and fresh enzymatic preparation was added to the remaining tissue fragments. Cells used in this study were obtained after $2 \mathrm{~h}$ of incubation with pronase. Cells were cultured at $37{ }^{\circ} \mathrm{C}$ in $5 \% \mathrm{CO}_{2}$ in Advanced DMEM/F12 medium (Gibco) containing $10 \%$ fetal calf serum (FCS), $2 \mathrm{mM} \mathrm{L}$-glutamine, $40 \mathrm{mM} \mathrm{N}$-(2-hydroxyethyl)-piperazine- $N$ ' -2 -ethanesulfonic acid (HEPES buffer, Biowhittaker), $200 \mathrm{U} / \mathrm{mL}$ penicillin (Sigma-Aldrich), $200 \mu \mathrm{g} / \mathrm{mL}$ streptomycin (Sigma-Aldrich), $0.5 \mu \mathrm{g} / \mathrm{mL}$ amphotericin B (Gibco) and $1 \mu \mathrm{g} / \mathrm{mL}$ hydrocortisone (Sigma-Aldrich). After $24 \mathrm{~h}$, attached cells were washed with HBSS and fresh medium was added. After 
3 days of culture, epithelial cells were enriched by selective trypsinization ( $0.25 \%$ trysin-EDTA). Detached cells after 5 min of trypsinization were discarded and fresh medium was added on the cells that remained attached to the plastic of the culture flasks. This selective trypsinization was repeated on day 6 and a first passage was performed two days later. Cells were then frozen under nitrogen after 2 passages. The PS cell line was obtained by selective trypsinization at passage 4 . The cells were subjected to 2 additional passages and frozen.

Cells were thereafter maintained in MEC growth medium (GM): Advanced-DMEM/F12 (Gibco) containing $20 \mathrm{mM}$ HEPES, $2 \mathrm{mM}$ L-glutamine (Gibco), $1 \mu \mathrm{g} /$ $\mathrm{mL}$ hydrocortisone (Sigma-Aldrich), $10 \mathrm{ng} / \mathrm{mL}$ Insulinlike growth factor (IGF)-1, $5 \mathrm{ng} / \mathrm{mL}$ Fibroblast growth factor (FGF), $5 \mathrm{ng} / \mathrm{mL}$ Epidermal growth factor (EGF).

\section{Cytology of the PS cell line}

In order to visualize the morphological features of the PS cell line in culture, a May-Grünwald Giemsa staining was performed on cells grown on 6-well plate. Cells were covered with May-Grünwald dye for $3 \mathrm{~min}$. The same volume of distilled water was added for $1 \mathrm{~min}$. After draining, Giemsa dye ( $8 \%$ in distilled water) was incubated for $20 \mathrm{~min}$ and the cells were washed with tap water.

\section{Flow cytometry analysis of PS cells}

Antibodies used in the present study are described in Additional file 1. Labellings were done on PS cells at passages 9, 14 and 18. Intracellular labelling for cytokeratins expression study was performed when cells formed a confluent monolayer. Cells were harvested after trypsin treatment (0.05\% trysin-EDTA -Gibco), and the cell pellet was resuspended in $500 \mu \mathrm{L}$ of permeabilization buffer Cytofix Cytoperm (BD Biosciences), and incubated in the dark at $4{ }^{\circ} \mathrm{C}$. After $20 \mathrm{~min}$, the cell suspension was washed with $1 \mathrm{~mL}$ of Perm Wash 1X buffer (BD Biosciences). The cells were collected, resuspended in Perm Wash $1 \mathrm{X}$ buffer, and were split into each well $\left(3 \times 10^{5} /\right.$ well in $20 \mu \mathrm{L}$ ) of a 96-well U-bottom well plate. The cells were then incubated with $20 \mu \mathrm{L}$ of primary antibody for $15 \mathrm{~min}$ at $4{ }^{\circ} \mathrm{C}$. The plate was washed with $100 \mu \mathrm{L}$ of Perm Wash buffer, and the cell pellet was resuspended in $50 \mu \mathrm{L}$ of the secondary antibody for 15 min at $4{ }^{\circ} \mathrm{C}$ when required.

Extracellular labelling was performed when MEC formed a confluent monolayer. Cells were harvested and distributed $\left(20 \mu \mathrm{L}, 3 \times 10^{5}\right.$ cells/well $)$ into 96-well Ubottom well plates. The cell suspension was resuspended in $20 \mu \mathrm{L}$ of antibodies against CD45, CD14 and CD282 (TLR2), and incubated for $15 \mathrm{~min}$ at $4{ }^{\circ} \mathrm{C}$. The cells were then washed with $100 \mu \mathrm{L}$ of buffer (DPBS without Ca and $\mathrm{Mg}$, Lonza; $2 \%$ goat serum, Gibco; 2 mM EDTA). The plate was centrifuged for $10 \mathrm{~min}$ at $200 \mathrm{~g}$, and, if necessary, the cell pellet was resuspended in $50 \mu \mathrm{L}$ of secondary antibodies, and incubated for $15 \mathrm{~min}$ at $4{ }^{\circ} \mathrm{C}$. Then the cells were washed and fixed with $150 \mu \mathrm{L}$ of FACS lysing solution (BD Biosciences). Peripheral blood mononuclear cells (PBMC) isolated from bovine blood were used as positive control for CD45 labelling. Fluorescence-activated cell sorting (FACS) analysis was performed on a FACSCalibur cytometer using CellQuest software (BD Biosciences) and data were analyzed with FlowJo software (Tree Star, Ashland, OR, USA).

\section{Stimulation of cells with live bacteria or purified bacterial agonists}

For each stimulation assay, each stimulus/strain was assessed in duplicate wells. PS cells were seeded at a concentration of $10^{5}$ cells $/ \mathrm{mL}$ in 24-well or 96-well plates and cultivated in GM medium until they formed a confluent monolayer. They were then cultured overnight $(16 \mathrm{~h})$ in fresh stimulating medium without growth factors (stimulation medium). Cells were then washed twice with HBSS and stimulated with either live bacteria or bacterial purified agonists diluted in stimulation medium at the indicated concentrations. For stimulation with $E$. coli strains 1303 or P4 [20], bacteria were grown overnight in stimulation medium at $37^{\circ} \mathrm{C}$ without agitation. On the day of the experiment, bacteria were diluted in stimulation medium and added to cells at a multiplicity of infection of 1 . Cells were incubated with bacteria for three hours at $37{ }^{\circ} \mathrm{C}$ in a humidified incubator with $5 \%$ $\mathrm{CO}_{2}$; bacteria were then removed, cells were washed twice with HBSS and stimulation medium containing $10 \mu \mathrm{g} / \mathrm{mL}$ gentamycin was added. Supernatant was collected $5 \mathrm{~h}$ or $21 \mathrm{~h}$ after addition of the gentamycin containing medium and cells were processed for RNA purification if necessary (see below). Agonists used were from InvivoGen: ultrapure lipopolysaccharide from $E$. coli O111:B4 strain (LPS), $\gamma$-D-glutamyl-meso-diaminopimelic acid (C12-iE-DAP), Pam2-CSK4, Pam3-CSK4, muramyl-dipeptide (MDP) and flagellin (FLA-ST Ultrapure). Cells were incubated with these purified agonists for $5 \mathrm{~h}$ at $37^{\circ} \mathrm{C}$ in a humidified incubator with $5 \% \mathrm{CO}_{2}$; supernatants were then collected and cells were processed for RNA purification if necessary. For RNA isolation, cells were lysed with RA1 lysing buffer (MachereyNagel) with $1 \% \quad \beta$-mercaptoethanol (Sigma-Aldrich). RNA was then extracted following the manufacturer's instructions (Macherey-Nagel). When required, $5 \mu \mathrm{g} / \mathrm{mL}$ of recombinant human soluble CD14 (CD14) (Biometec $\mathrm{GmbH}$, Germany), $5 \mu \mathrm{g} / \mathrm{mL}$ of recombinant human LPS-binding protein (LBP) (Biometec $\mathrm{GmbH}$ ) or fresh whole milk were used to supplement the culture medium of PS cells. Fresh whole milk was collected on the day of the experiment from a healthy Prim'Holstein cow from the Unité Expérimentale de Physiologie Animale de 
l'Orfrasière (INRA Tours). IL-17A was used as described previously at a concentration of $100 \mathrm{ng} / \mathrm{mL}$ [13]. Primary cells were isolated and grown as previously described and used at their third passage $[16,21,22]$.

\section{ELISA assays}

CXCL8, IL-17A and TNFa production by PS cells was quantified by sandwich ELISA, with reference to standard as described previously $[23,24]$. IL- $1 \beta$ was quantified by ELISA using the Bovine IL-1 beta ELISA Reagent Kit (Thermo Scientific).

\section{Transcript analysis by RT-PCR and RT-qPCR}

Total RNA $(1 \mu \mathrm{g})$ was reverse transcribed to cDNA using random hexamers and SuperScript RT III (Invitrogen) according to manufacturer's instructions. Primers used in this study are listed in Additional file 2 and [13]. Expression of PRRs was analyzed by RT-PCR using 40 amplification cycles. Relative quantities of transcripts of interest were analyzed by RT-qPCR as described previously [13]. Briefly, after normalization using the expression of 3 reference genes (Actb, PPIA, 18S RNA), expression of each gene was calculated relative to the values obtained from unstimulated cells arbitrarily set to 1 .

\section{Statistical analysis}

In vivo gene expression results were analysed by a permutation test using the StaXact software (v5.0-Cytel software) to obtain exact $p$-values. For the analysis of responses of MEC cells to the different bacterial agonists or to live bacteria, data were first compared using the Kruskal and Wallis test followed by exact permutation tests using StatXact. A $p$-value $<0.05$ was considered significant.

\section{Results}

IL-17A and IL-17 F gene expression is induced upon infection of the udder by $E$. coli

Previous reports showed that experimental intramammary inoculation of Escherichia coli 1303 induced a significant host response [25]. Based on microarray analyses, expression of cytokines and chemokines such as CCL20 and CXCL8 was shown to be increased upon $E$. coli 1303 infection 514 and 58-fold, respectively [15]. Our RT-qPCR data confirmed that, upon infection with E. coli 1303, expressions of CCL20 and CXCL8 genes were induced, approx. 16 000-fold and 108-fold, respectively (Figures 1A and B). A higher expression, compared to uninfected cows, was also detected, particularly with CCL20, in uninfected quarters of three out of five E. coli infected cows which is consistent with a systemic effect as previously reported $[19,26]$.

Microarray experiments had failed to detect a significant expression of IL-17 family genes in udder tissue after $E$. coli infection, presumably because of a low expression of these genes [15]. In the present study, we thus used RT-qPCR to evaluate the expression of IL-17 family genes. No expression was detected for IL-17C and IL-17E (data not shown). On the contrary, expression of IL-17A and IL-17F was significantly increased in $E$. coli infected quarters, compared to non-infected quarters (Figures $1 \mathrm{C}$ and $\mathrm{D}$ ): the mean fold-change for IL-17A was 72 in samples from cows infected by E. coli. Mean induction of IL-17F was 109-fold in the same samples (Figures 1C and D). Although induction of IL17A gene was clearly observed in our tissue samples, IL17A levels in milk samples from E. coli infected cows were below the detection limit of the ELISA assay used, that is below $200 \mathrm{pg} / \mathrm{mL}$ in milk.

Despite this lack of detection of IL-17A in milk from infected quarters, gene expression results suggest that IL-17A and IL-17F may play a role in the immune response of cows to intra-mammary infection, either at the onset of or during the inflammatory response.

Considering that IL-17A has generally more potent effects than IL-17F on epithelial cells [13], we then explored if IL-17A in particular could contribute to the defence of the host against $E$. coli infection by modulating the innate immune response of MEC. Indeed, these cells are key players in mounting an efficient early innate immune response and IL17-A has been shown to target a variety of cell types, in particular epithelial cells [27-29].

\section{PS cells as a useful tool to study the innate immune response of mammary epithelial cells}

Although pbMEC are often used to study the response of MEC to infection, the use of primary epithelial cell cultures has a number of drawbacks. Most importantly, variability of response of pbMEC from different animals on the one hand and lack of reproducibility of experiments on the other hand, can be associated with contamination of primary cell cultures with other cell types, and the amount of these contaminating cells can vary from one primary culture to another. Considering that these contaminating cells could exacerbate or lower the innate immune response of MEC through cooperation, we decided to use a new mammary epithelial cell line showing innate immune response capabilities to perform these assays.

This cell line, which we called the PS cell line, stems from spontaneously immortalized cells that emerged from a culture of primary bovine MEC isolated from the secretory parenchyma of a cow (hence the name PS cells). Upon reaching confluency, they form a homogeneous layer of cells with cobblestone morphology typical of epithelial cells (Additional file 3). This cell line was also characterized for potential contamination by leukocytes (CD45-positive cells) and for expression of cell 


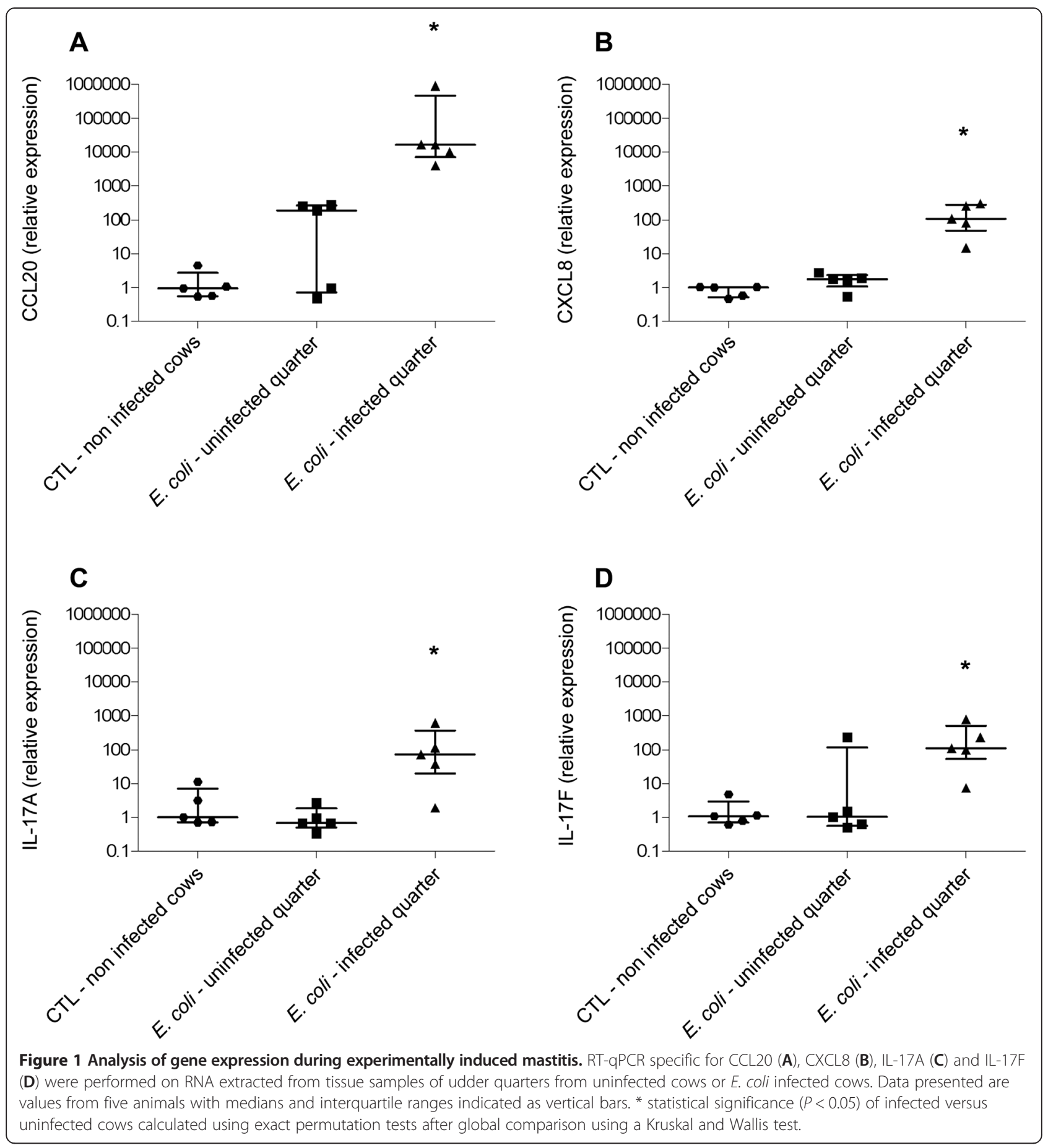

surface markers associated with mammary epithelial cells. Results indicated a percentage of CD45-positive cells similar to background level $(0.6 \%)$ and expression of cytokeratin 18 by more than $99.5 \%$ of cells. Cytokeratin 14 was only weakly expressed by PS cells (Figures 2A-F).

RT-PCR data indicated that these cells expressed several genes encoding Pattern Recognition Receptors (PRR) such as TLR1, TLR2, TLR4, TLR6, NOD1 and
NOD2 (Figure 2G) as well as the genes encoding the two subunits of the IL-17A receptor, namely IL-17RA and IL-17RC (Figure 2H). While the weak amplification of TLR5 cDNA was consistent with previous results obtained with primary epithelial cells [16], a weak amplification of TLR2 cDNA was observed. Despite this low expression of TLR2, FACS analysis showed that the TLR2 protein was actually present at the surface of PS cells (Figure 2D). 


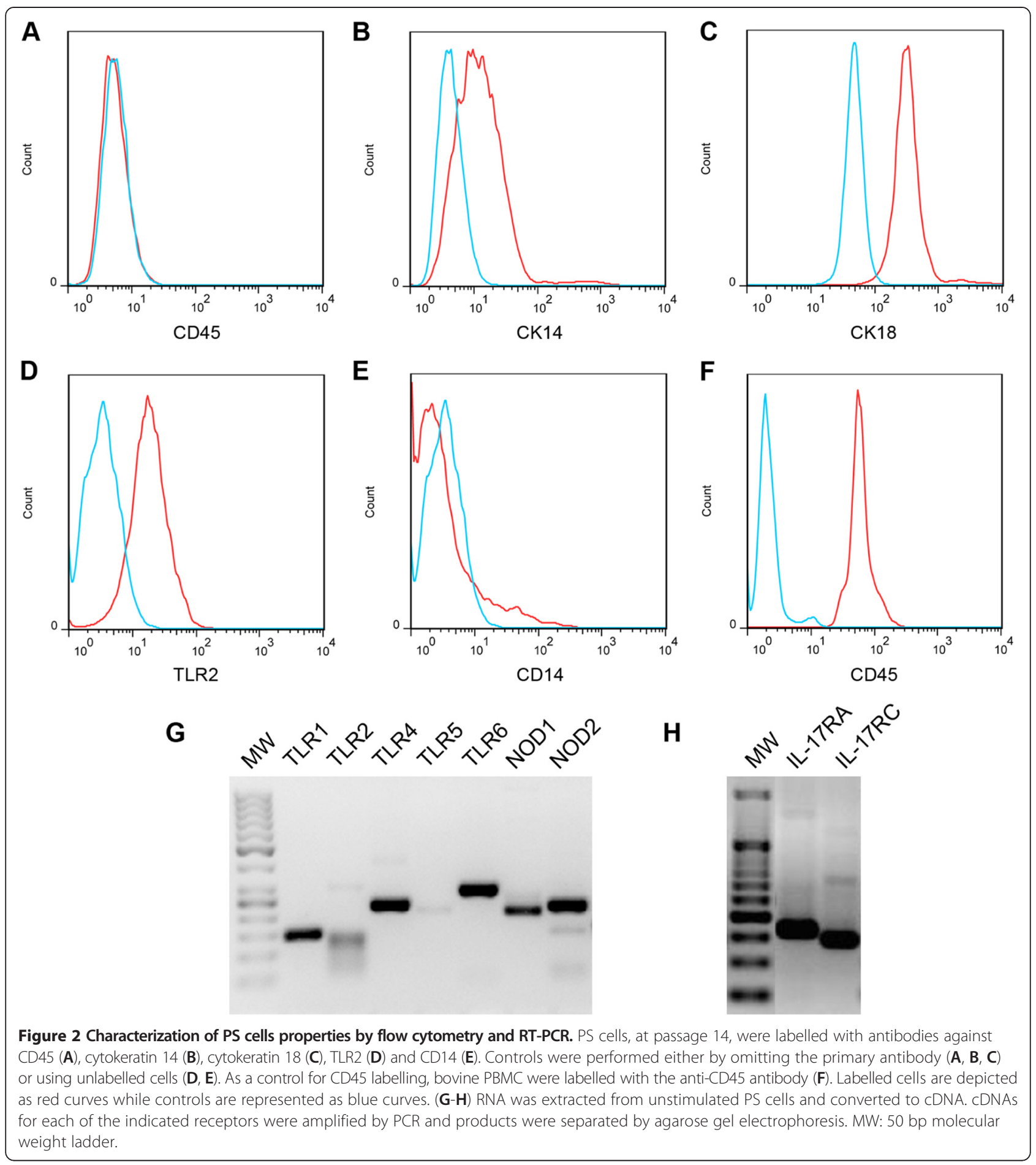

In order to use these cells to study the innate immune response, we analysed their capacity to respond to stimuli such as lipopolysaccharide (LPS), lipoteichoic acid (LTA), lipoproteins or peptidoglycan degradation products. The synthetic molecules Pam2-CSK4 and Pam3-CSK4 are analogs of di-acylated and tri-acylated lipoproteins that signal through the TLR2/TLR6 or TLR1/TLR2 heterodimers, respectively. C12-iE-DAP and MDP are peptidoglycan subunits that are sensed by the NOD1 and NOD2 receptors, respectively. When PS cells were exposed to these MAMPs, the highest response was observed with Pam2-CSK4 at $100 \mathrm{ng} / \mathrm{mL}$ (Figure 3): compared to non-induced cells, Pam2-CSK4 induced an overexpression of CCL20, CXCL8 and TAP, three genes whose 

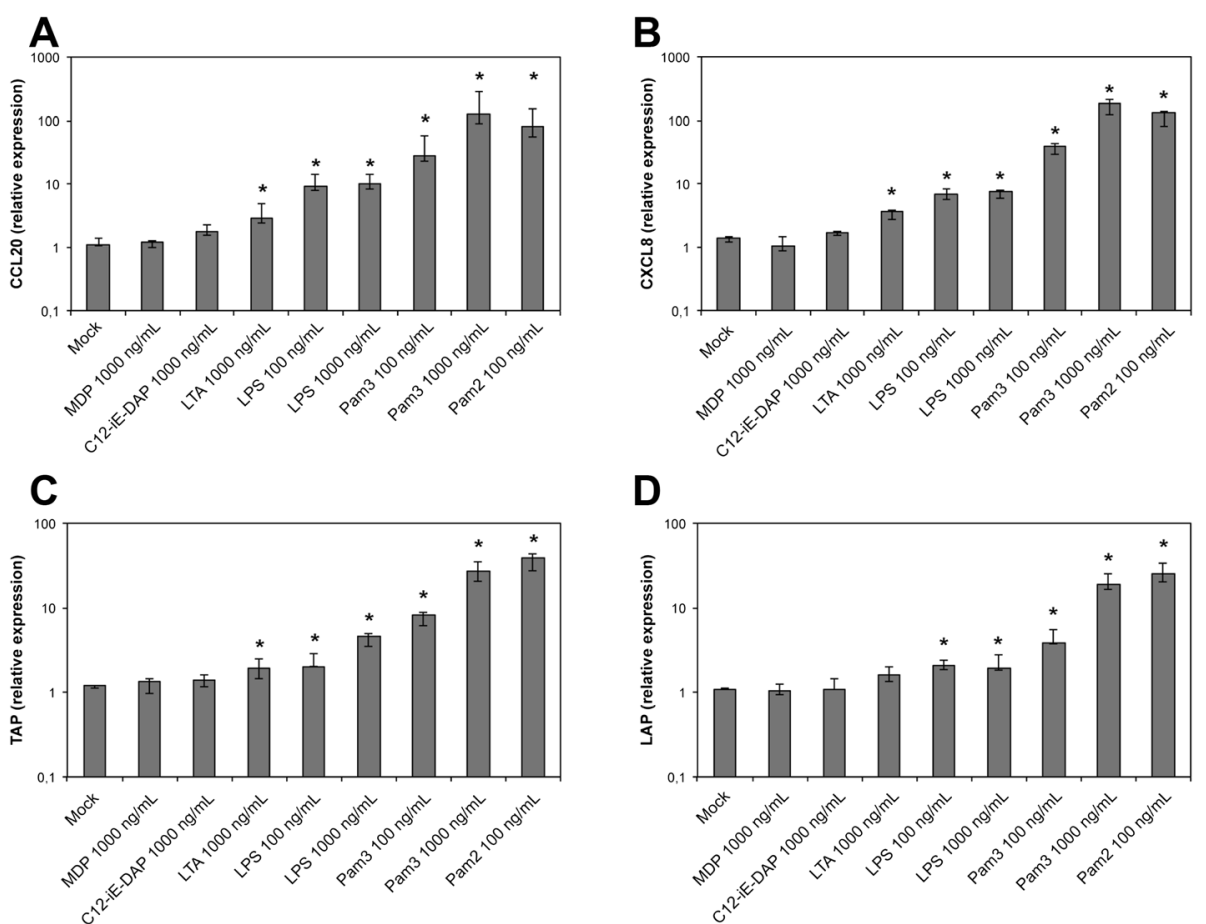

$\mathbf{D}$
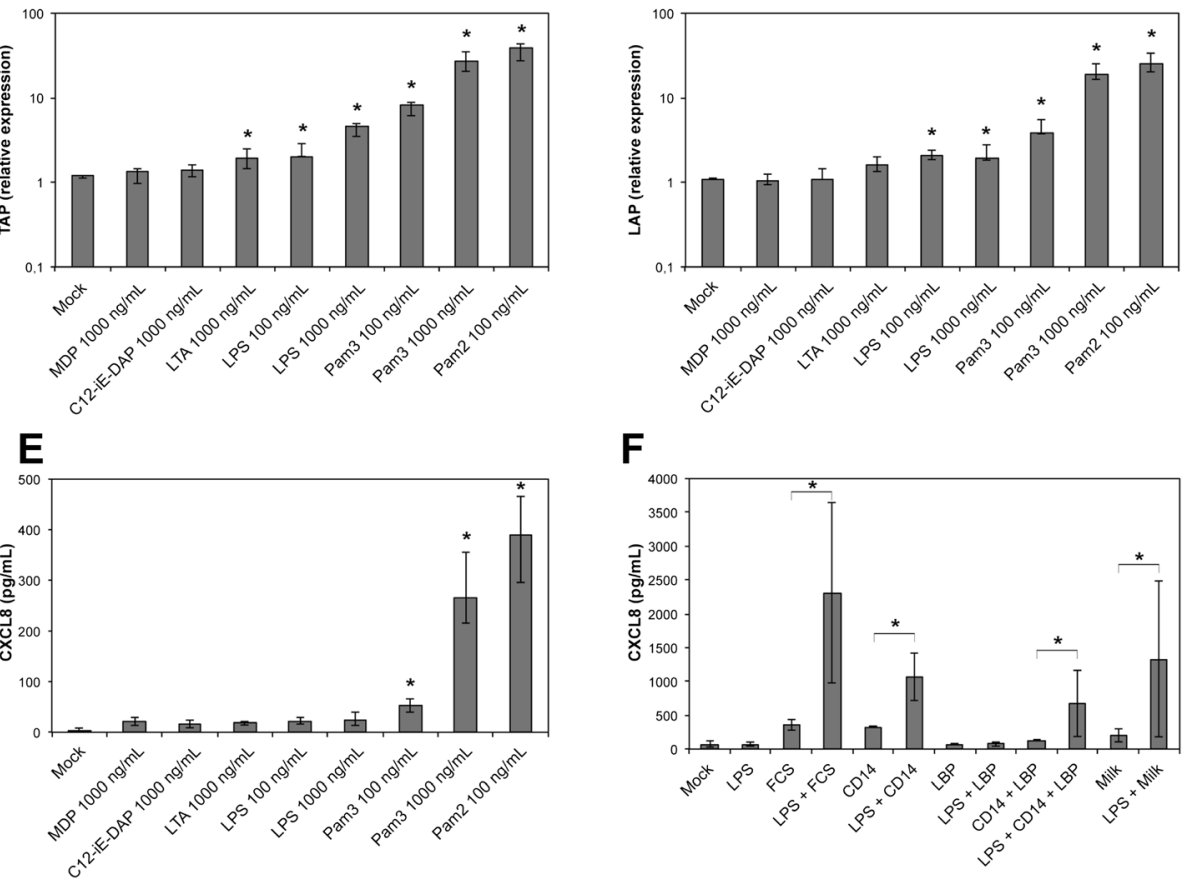

Figure 3 Innate immune response of PS cells to different purified bacterial agonists. PS cells were incubated for $\mathbf{5}$ h with the indicated concentrations of different purified agonists. Response was analyzed in terms of expression of CCL20 (A), CXCL8 (B), TAP (C), LAP (D) genes by RT-qPCR or CXCL8 secretion by ELISA (E,F). Data presented are mean values and SD obtained from 3 independent experiments. Experiments were performed at passages 11,12 and 24. PS cells were incubated for 5 hours in GM medium with different agonists at the indicated concentrations. (F) PS cells were incubated with ultrapure LPS (LPS) at $10 \mathrm{ng} / \mathrm{mL}$ in the presence of either $10 \%$ fetal calf serum, $5 \mu \mathrm{g} / \mathrm{mL}$ CD 14 or $5 \mu \mathrm{g} / \mathrm{mL}$ LBP. Stimulation was also performed in whole milk instead of GM medium. ${ }^{*}$ statistical significance $(P<0.05)$ of stimulated versus unstimulated PS cells using exact permutation tests after global comparison using a Kruskal and Wallis test.

expression is induced upon stimulation of mammary epithelial cells [15], and induced also the secretion of CXCL8 (Figure 3E). PS cells also responded to Pam2-CSK4 when used at $10 \mathrm{ng} / \mathrm{mL}$ (data not shown). A significant but lower response was observed with Pam3-CSK4, both in terms of increased expression of CCL20, CXCL8, TAP and LAP and increased secretion of CXCL8 (Figure 3). No response was observed with both MDP and C12-iE-DAP (Figure 3). In a separate experiment, a concentration of flagellin of $100 \mathrm{ng} / \mathrm{mL}$ only induced a weak increase in TAP expression (3-fold) but failed to induce significant secretion of CXCL8 and increased expression of CCL20 (data not shown). Interestingly, response of PS cells to LPS required the addition of CD14 in the culture medium. Under serum-free conditions, PS cells responded only weakly to LPS. Nevertheless, CXCL8 secretion in response to $10 \mathrm{ng} / \mathrm{mL}$ LPS was increased in the presence of $5 \mu \mathrm{g} / \mathrm{mL}$ CD14 $(1067 \mathrm{pg} / \mathrm{mL})$ compared to only $67 \mathrm{pg} / \mathrm{mL}$ in the absence of CD14 (Figure 3E). On the contrary, supplementing the medium with LBP did not improve the response of PS cells to LPS. This indicates that CD14 is essential for the recognition of LPS by the PS cell line in our culture conditions. In the presence of serum (10\% FBS), the PS cells produced CXCL8 in response to LPS, and CXCL8 

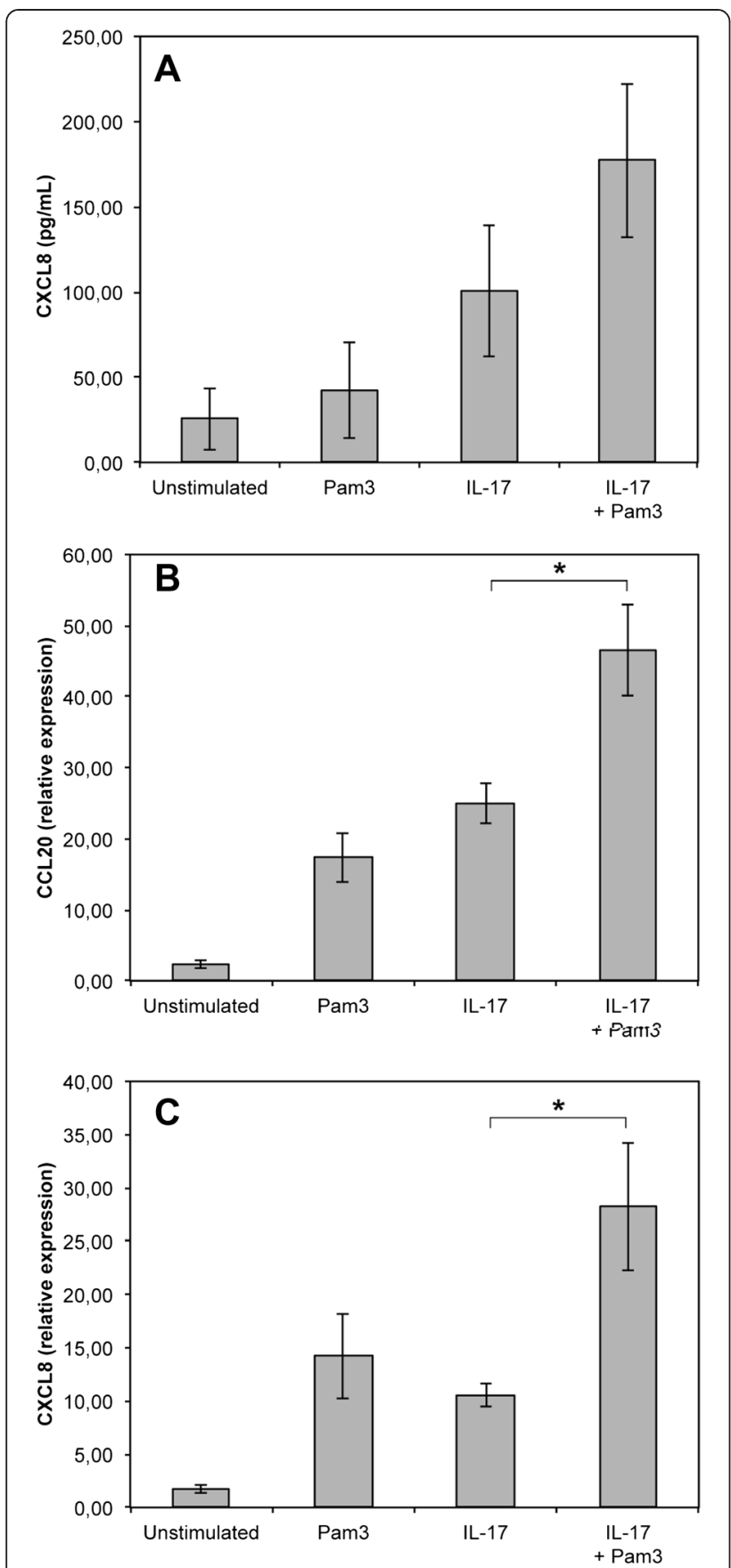

Figure 4 IL-17A effect on the response of PS cells to Pam3-CSK4. PS cells were incubated for $5 \mathrm{~h}$ with $100 \mathrm{ng} / \mathrm{mL}$ of Pam3-CSK4 in the presence or not of $100 \mathrm{ng} / \mathrm{mL} I \mathrm{~L}-17 \mathrm{~A}$. Response was analyzed in terms CXCL8 secretion (A) by ELISA or expression of CCL20 (B) and CXCL8 (C) by RT-qPCR. Data presented are mean values and SD obtained from 3 independent experiments. Experiments were performed at passages 15,16 and $24 .{ }^{*}$ statistical significance $(P<0.05)$ calculated using exact permutation tests after global comparison using a Kruskal and Wallis test. production also occurred when the LPS stimulation was performed in fresh milk (Figure 3). This is in keeping with the occurrence of sCD14 in serum and bovine milk [30].

Compared to the response of primary cells to these same agonists, PS cells responded to a similar array of bacterial compounds, although their response was somewhat lower than that of pbMEC (Additional file 4). Furthermore, stimulation experiments performed at different passages indicated that the PS cell line is stable at least up to passage 24 (Additional file 4).

PS cells could thus be used as a surrogate to pbMEC to monitor the innate response of mammary epithelial cells and, in the present report, how this response can be modulated by IL-17A.

\section{IL-17A increases the response of PS cells to Pam3-CSK4}

In a first attempt to investigate how IL-17A could modulate the response of MEC, we analysed the response of PS cells to purified bacterial agonists in the presence or not of IL-17A. We selected LPS and Pam3-CSK4, activating TLR4 and TLR $1 / 2$, respectively, as they are likely to represent the most relevant agonists in vivo through which $E$. coli stimulates MEC and they induce a strong innate response in pbMEC [16] and PS cells (see Figure 3).

When PS cells were stimulated with both Pam3-CSK4 and IL-17 for 5 hours, the response in terms of CCL20 and CXCL8 gene expression was significantly increased compared to the response observed only in the presence of IL-17A or Pam3-CSK4 (Figure 4). The increase in terms of CXCL8 secretion, although significant statistically, was less important. The impact of IL-17A on the response of PS cells to LPS was also statistically significant but of lower magnitude. A clear response of PS cells to LPS was observed in the presence of CD14 with high level of secretion of CXCL8 and strong induction of CCL20 and CXCL8 gene expression (Figure 5). Secretion of CXCL8 was increased 1.5 fold when IL-17 was present along with LPS and CD14. In the same conditions, IL17A induced only a small increase of CCL20 gene expression while no significant impact on CXCL8 gene expression was observed. Interestingly, although PS cells responded very weakly to LPS in the absence of CD14, we could observe that IL-17 increased slightly the response of PS cells when they were stimulated with LPS alone (Figure 5).

\section{IL-17A increases the response of MEC to live $E$. coli}

We next analysed if IL-17A could also increase the response of MEC to live bacteria. We used a protocol previously described which allowed stimulation of cells with live bacteria while avoiding a change in $\mathrm{pH}$ of the culture medium due to bacterial outgrowth [21]: briefly, cells were incubated in the presence of bacteria for three hours. Bacteria were then washed away, medium containing 

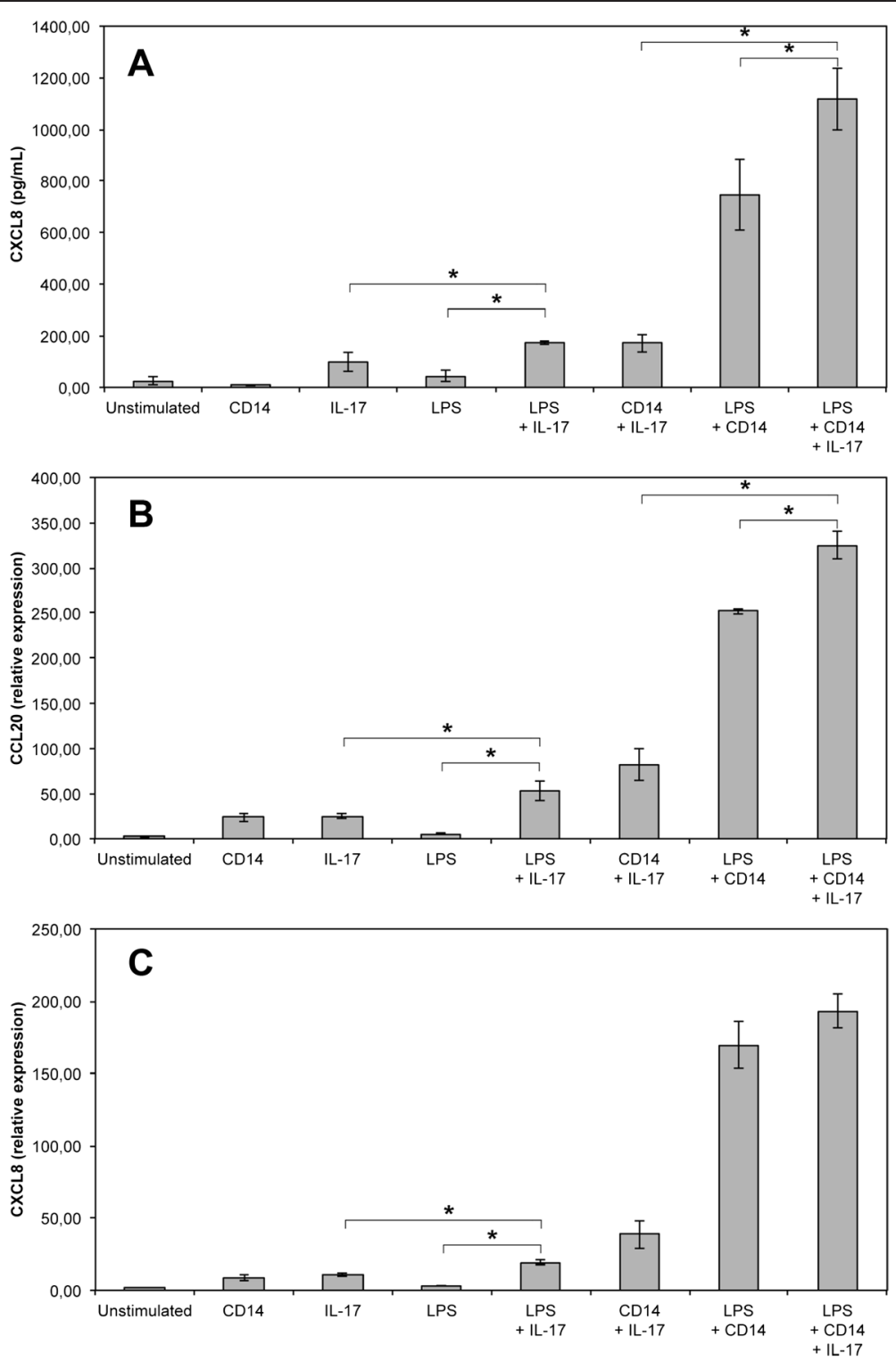

Figure 5 IL-17A effect on the response of PS cells to LPS. PS cells were incubated for $5 \mathrm{~h}$ with $10 \mathrm{ng} / \mathrm{mL}$ of LPS in the presence or not of $100 \mathrm{ng} / \mathrm{mL}$ IL-17A and $5 \mathrm{\mu g} / \mathrm{mL}$ CD14. Response was analyzed in terms CXCL8 secretion (A) by ELISA or expression of CCL20 (B) and CXCL8 (C) by RT-qPCR. Data presented are mean values and SD obtained from 3 independent experiments. Experiments were performed at passages 15,16 and 24. * statistical significance $(P<0.05)$ calculated using exact permutation tests after global comparison using a Kruskal and Wallis test.

gentamycin was added with or without IL-17A and incubation was prolonged for $5 \mathrm{~h}$ (for RT-qPCR analyses) or $21 \mathrm{~h}$ (for ELISA assays of CXCL8 secretion).

Results indicated that IL-17A increased the response of PS cells when they were stimulated with either E. coli strain 1303 or E. coli $\mathrm{P} 4$, a prototypical mastitis isolate. Expression of CCL20, CXCL8 and TAP were significantly increased upon addition of IL-17A in the culture medium (Figure 6). Similarly, secretion of CXCL8 was increased 1.5 fold and 3.1 -fold in PS cells stimulated with strains 1303 and P4, respectively (Figure 6D).
We observed a similar increase in innate response mediated by IL-17A using primary cells (Figures 6E-F). An increase in CXCL8 secretion was observed with primary cells from two different cows using E. coli $\mathrm{P} 4$ and, to a somewhat lower extent, with E. coli 1303 . These results indicate that the increased pro-inflammatory response triggered by IL-17A is not restricted to PS cells. In addition, the fact that these primary cells do not require addition of CD14 in the medium to respond to LPS [16] suggests that the effect of IL-17A does not depend on supplementation of the medium with CD14. 


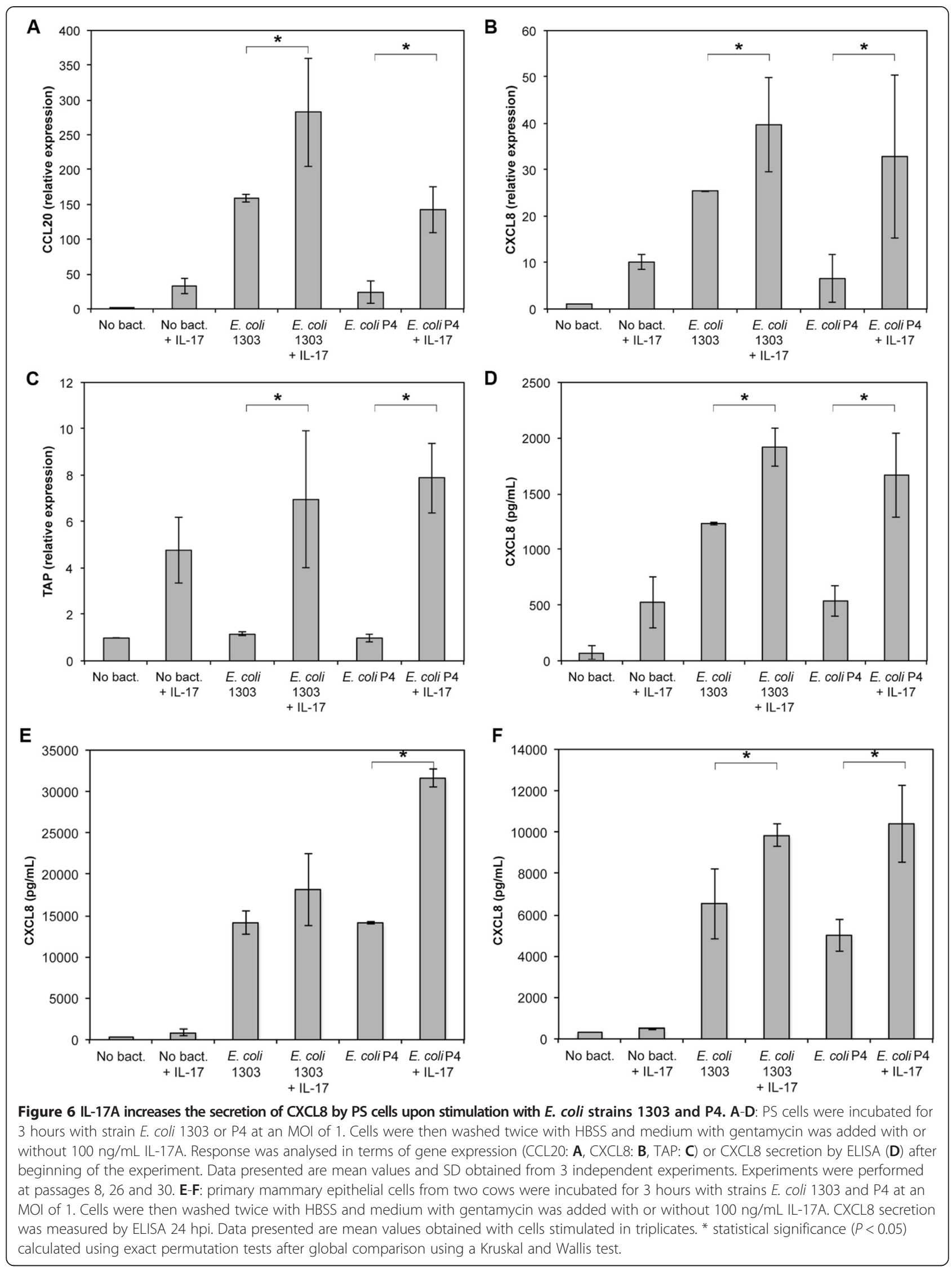


Because synergies involving IL-17A have been described with IL-1 $\beta$ and TNF $\alpha$ we quantified IL-1 $\beta$ and TNF $\alpha$ in the supernatant of stimulated PS cells: amounts of IL- $1 \beta$ and TNF $\alpha$ were below the detection limit of the ELISA assays used $(50 \mathrm{pg} / \mathrm{mL}$ for TNF $\alpha$ and $30 \mathrm{pg} / \mathrm{mL}$ for IL-1 $\beta$ ).

\section{Discussion}

The main objective of this report was to investigate if cytokines of the IL-17 family could play a role in the defence of cows against intramammary infections. This question is of particular relevance given the important role of IL-17 proteins in the defence of different hosts against a range of bacterial infections [28,31]. In addition, several reports indicate that IL-17 can be detected in bovine milk in different experimental settings. Production of IL-17A was recently demonstrated in the course of $S$. uberis infection [10]. Furthermore, vaccination of cows with a model antigen could induce a Th17 cell-mediated immune response characterized by the production, in particular, of IL-17A in the mammary gland [24]. The udder has therefore the ability to secrete IL-17A but its contribution to the defence against $E$. coli mastitis has not been investigated.

From the data presented in this report, we can clearly conclude that expression of IL-17A and IL-17F genes is induced approx. 100-fold upon infection by E. coli. We were however unable to detect any secretion of IL-17A in milk from E. coli infected quarters. So far, production of IL-17A in an infected udder was only reported in clinical mastitis after experimental Streptococcus uberis infection. Yet, IL-17A only reached significant levels after $56 \mathrm{~h}$ (peak level at $81 \mathrm{~h}$ ), long after other cytokines had reached the peak level [10]. It is therefore possible that IL-17A levels could be detected in milk at later time points in the case of $E$. coli infections, explaining our failure to measure IL-17A in milk from $E$. coli infected cows 24 hours post-infection. Preliminary results indicates that expression of IL-17A and IL-17F genes is also induced in samples from quarters infected by the $S$. aureus strain 1027 (data not shown). Overall, expression of IL-17A and IL-17F genes during infection raise the point of the contribution of these cytokines to the defence of the udder against bacterial infection.

These cytokines are generally considered to act on epithelial cells as well as on endothelial and stromal cells by inducing, for example, expression of antimicrobial peptides and neutrophil-activating molecules [31]. We recently showed that, in vitro, IL-17A and IL$17 \mathrm{~F}$ were likely to improve the innate defences of the host through modulation of gene expression patterns of MEC [13]. More precisely, primary MEC express IL$17 \mathrm{~A}$ and IL-17F receptor genes and respond to the presence of IL-17A by increased expression of different pro-inflammatory mediators such as CXCL8, CCL20, IL- 6 or IL-1 $\beta$ [13].

We therefore chose to investigate in more details if IL$17 \mathrm{~A}$ could increase the response of the host to $E$. coli infection by modulating the pro-inflammatory response of MEC. To achieve this goal, we used a new cell line that we recently isolated. Prior to performing experiments with IL-17A, we characterized these cells in terms of expression of markers typical for MEC and in terms of response to purified compounds, as we had already done with primary cells [16].

The PS cell line was found to be stable, in terms of cell morphology (data not shown) and response to MAMPs, and displays a cobblestone aspect which is consistent with epithelia characteristics. The strong surface expression of CK18 and the low expression of CK14 allowed us to establish that PS cells are effectively from epithelial origin and of luminal nature [32-35]. The luminal character of PS cells is also indicated by the fact that PS cells formed unorganized clones and express PRRs $[17,36]$. The high percentage of CK18-positive cells, along with the lack of CD45 labelling, attested to the purity of this cell line and the absence of leukocytes. Additionally, these cells were shown to express $\alpha$-casein gene CSN1S1, a proof of their secretory capacity, in accordance with their origin (i.e. secretory parenchyma) (E. Devinoy, M. Nguyen, personal communication).

Similar to pbMEC, PS cells express several PRRs, including TLR1, TLR2, TLR4, TLR6, NOD1 and NOD2 $[16,25,36,37]$. Consistent with the expression of TLR1, TLR2, TLR4 and TLR6, PS cells were able to respond to the presence of bacterial agonists that stimulates through these receptors such as the analogs of lipoproteins Pam 2-CSK4 and Pam 3-CSK4, and LPS provided CD14 is added in the culture medium.

Actually, the response of PS cells to LPS in the absence of CD14 was rather weak compared to what had already been described [16,37-39] and given the strong inflammation triggered by LPS infusion in the udder [40-42]. Supplementing our stimulation medium with purified CD14, or raw milk, resulted in a substantial increase of the immune response of PS cells to LPS. Others have reported similar findings with pbMEC [30]. These data suggest that the presence of CD14 in milk contributes to the response of MEC to LPS and concur with the observations that 1) concentrations of CD14 in milk are less than optimal and 2) that response of the host can be improved when CD14 is infused into the udder along with the E. coli inoculum [43].

As for flagellin, the absence of TLR5 transcript observed either with PS cells or primary MEC, along with the weak response induced by purified flagellin, are in agreement with previous in vitro and in vivo studies that suggest that flagellin is not a major contributor to 
the inflammatory response of the udder to $E$. coli infection $[16,44]$.

The possibility that PS cells would de-differentiate after several passages, as was observed by Gunther et al. [15], was ruled out by showing that PS cells were still capable of inducing LAP expression upon stimulation with MAMPs.

Altogether, these results indicate that PS cells are useful surrogates to pbMEC in the understanding of innate immune response of MEC to MAMPs.

After having verified that PS cells expressed the genes encoding for the two sub-units of the IL-17A receptor, we used PS cells to investigate whether IL-17A could contribute to an increased innate immune response of MEC upon stimulation with purified bacterial compounds. Our results demonstrate that this could be the case as secretion of CXCL8, as well as expression of CCL20 and CXCL8 genes, are significantly increased when cells are incubated for 5 hours with IL-17A and purified Pam3-CSK4 or, to a lower extent, LPS. We were only able to detect an additive effect with no real synergy.

More interestingly, a synergy between IL-17A and innate response of MEC was observed when stimulation was performed with live bacteria. These results, initially obtained with PS cells, were confirmed with primary cells and extend the ones we obtained previously with purified bacterial compounds related to Gram-positive bacteria, i.e. MDP and LTA [13].

Our results are reminiscent to synergy observed with other mediators such as TNF $\alpha$ or IL-1 $\beta$. [45-47]. Yet, we did not detect any IL-1 $\beta$ nor TNF $\alpha$ after stimulation of PS cells with live E. coli. It is therefore unlikely that production of these pro-inflammatory mediators could explain the synergies we observed. To explain such results, one should take into account the multiple activities of IL-17A both on induction of expression and on stabilization of mRNA transcripts.

The increased response of PS cells is most likely due to the stabilization of mRNA transcripts following IL17A recognition as was observed for CXCL1 [48-50]. It could also be due to an increased expression of PRR genes such as TLR2 or TLR4. A third alternative is that expression of the IL-17A receptor at the surface of PS cells is increased after infection by E. coli. Yet, in the absence of suitable reagent, such a possibility cannot be tested. The origin of the synergy observed will have to be further investigated.

Another major issue concerns the characterization of the cells that overexpress the genes for IL-17A and IL-17F upon $E$. coli infection. Immunocytochemistry analyses suggested that MEC or interstitial cells, presumably lymphocytes, could produce IL-17A upon inflammatory challenge [24]. Interestingly, one of the genes assayed in our work, CCL20, encodes a ligand for the CCR6 receptor which is expressed by effector memory T cells, including Th17 cells [51]. As a consequence, the increased expression of CCL20 that we detected in our assays could also participate to the amplification of the host response to infection by attracting more IL-17-producing $\mathrm{T}$ cells to the site of infection.

In conclusion, our results show a marked overexpression of the genes encoding IL-17A and IL-17F in the mammary gland during $E$. coli infections which, by extending previous observation of overexpression during $S$. uberis udder infections, strongly suggest that these cytokines and the cells that produce them are important players of host-pathogen interactions during mastitis. Most interestingly, we were able to demonstrate that a potential role for IL-17A is to increase the pro-inflammatory and antimicrobial responses of MEC after $E$. coli infection. These results are also interesting in the scope of vaccine development. As a matter of fact, the protocol used in the present manuscript using live bacteria mimics the in vivo situation encountered by the bacteria entering the udder of vaccinated animals. In such cases, it is expected that the first response of MEC occurs in the absence of IL-17A, IL-17A coming into play only in a second step when memory Th17 cells have been activated. Our results are thus a strong incentive to further investigate the contribution of IL-17A to the defence of the mammary gland.

\section{Additional files}

Additional file 1: Antibodies list. List of antibodies used in this study. Additional file 2: Primer table. List of primers used in this study. Additional file 3: Microscopic examination of PS cells. A, PS cells were photographed under phase contrast (100x). B, PS cells after May Grünwald-Giemsa straining (200x).

Additional file 4: Innate immune response of PS cells and pbMEC to different purified bacterial agonists. pbMEC from two cows (white bars) and PS cells at passages 10 and 24 (grey bars) were incubated for $5 \mathrm{~h}$ with the indicated concentrations of different purified agonists. Response was analyzed in terms of expression of CCL20, TAP, LAP and CXCL8 genes by RT-qPCR. Data are mean values of stimulations performed in duplicates.

Competing interests

The authors declare that they have no competing interests.

Authors' contributions

PG, PRa, PRo, HZ, WP, CR, PC and FBG conceived the study and participated in its design and coordination. WP carried out all animal experiments. PRa, PC, FBG and CR isolated PS cells and primary cells. PRo, AP, PC and PG performed and analyzed stimulation of PS and primary epithelial cells and expression of PRR data. PRo and PG wrote the manuscript. FBG, PRa and WP helped writing the final version of the manuscript. All authors read and approved the final manuscript. 


\section{Acknowledgments}

Dr P. Roussel was recipient of a grant from the "Microbiology and Food Chain" and "Animal Health" divisions of INRA. We wish to thank Dr Eve Devinoy and Dr Minh Nguyen for sharing preliminary data.

\section{Author details}

${ }^{1}$ INRA, UMR1282, Infectiologie et Santé Publique, F-37380 Nouzilly, France. 2Université François Rabelais de Tours, UMR1282, Infectiologie et Santé Publique, F-37000 Tours, France. ${ }^{3} \mathrm{Clinic}$ for Ruminants with Ambulatory and Herd Health Services at the Centre for Clinical Veterinary Medicine, Ludwig-Maximilians University Munich, Oberschleissheim, Germany.

\section{Received: 23 October 2014 Accepted: 5 May 2015}

\section{Published online: 11 June 2015}

\section{References}

1. Schukken $\mathrm{YH}$, Gunther J, Fitzpatrick J, Fontaine MC, Goetze L, Holst O, Leigh J, Petzl W, Schuberth HJ, Sipka A, Smith DG, Quesnell R, Watts J, Yancey R, Zerbe H, Gurjar A, Zadoks RN, Seyfert HM (2011) Host-response patterns of intramammary infections in dairy cows. Vet Immunol Immunopathol 144:270-289

2. Riollet C, Rainard P, Poutrel B (2000) Differential induction of complement fragment $\mathrm{C} 5 \mathrm{a}$ and inflammatory cytokines during intramammary infections with Escherichia coli and Staphylococcus aureus. Clin Diagn Lab Immunol 7:161-167

3. Shuster DE, Kehrli ME Jr, Rainard P, Paape M (1997) Complement fragment C5a and inflammatory cytokines in neutrophil recruitment during intramammary infection with Escherichia coli. Infect Immun 65:3286-3292

4. Bannerman DD, Paape MJ, Lee JW, Zhao X, Hope JC, Rainard P (2004) Escherichia coli and Staphylococcus aureus elicit differential innate immune responses following intramammary infection. Clin Diagn Lab Immunol 11:463-472

5. Burvenich C, Van Merris V, Mehrzad J, Diez-Fraile A, Duchateau L (2003) Severity of $E$. coli mastitis is mainly determined by cow factors. Vet Res 34:521-564

6. Jain NC, Schalm OW, Lasmanis J (1971) Experimentally induced coliform (Aerobacter aerogenes) mastitis in normal cows and in cows made neutropenic by an equine anti-bovine leukocyte serum. Am J Vet Res 32:1929-1935

7. Vangroenweghe F, Rainard P, Paape M, Duchateau L, Burvenich C (2004) Increase of Escherichia coli inoculum doses induces faster innate immune response in primiparous cows. J Dairy Sci 87:4132-4144

8. Iwakura $Y$, Ishigame H, Saijo S, Nakae S (2011) Functional specialization of interleukin-17 family members. Immunity 34:149-162

9. Sivick KE, Schaller MA, Smith SN, Mobley HL (2010) The innate immune response to uropathogenic Escherichia coli involves IL-17A in a murine model of urinary tract infection. J Immunol 184:2065-2075

10. Tassi R, McNeilly TN, Fitzpatrick JL, Fontaine MC, Reddick D, Ramage C, Lutton M, Schukken YH, Zadoks RN (2013) Strain-specific pathogenicity of putative host-adapted and nonadapted strains of Streptococcus uberis in dairy cattle. J Dairy Sci 96:5129-5145

11. Tao W, Mallard B (2007) Differentially expressed genes associated with Staphylococcus aureus mastitis of Canadian Holstein cows. Vet Immunol Immunopathol 120:201-211

12. Gilbert FB, Cunha P, Jensen K, Glass EJ, Foucras G, Rupp R, Rainard P (2013) Differential response of bovine mammary epithelial cells to Staphylococcus aureus or Escherichia coli agonists of the innate immune system. Vet Res 44:40

13. Bougarn S, Cunha P, Gilbert FB, Harmache A, Foucras G, Rainard P (2011) Staphylococcal-associated molecular patterns enhance expression of immune defense genes induced by IL-17 in mammary epithelial cells. Cytokine 56:749-759

14. Gunther J, Esch K, Poschadel N, Petzl W, Zerbe H, Mitterhuemer S, Blum H, Seyfert HM (2011) Comparative kinetics of Escherichia coli- and Staphylococcus aureus-specific activation of key immune pathways in mammary epithelial cells demonstrates that $S$. aureus elicits a delayed response dominated by interleukin-6 (IL-6) but not by IL-1A or tumor necrosis factor alpha. Infect Immun 79:695-707

15. Gunther J, Koczan D, Yang W, Nurnberg G, Repsilber D, Schuberth HJ, Park Z, Maqbool N, Molenaar A, Seyfert HM (2009) Assessment of the immune capacity of mammary epithelial cells: comparison with mammary tissue after challenge with Escherichia coli. Vet Res 40:31
16. Porcherie A, Cunha P, Trotereau A, Roussel P, Gilbert FB, Rainard P, Germon P (2012) Repertoire of Escherichia coli agonists sensed by innate immunity receptors of the bovine udder and mammary epithelial cells. Vet Res 43:14

17. Strandberg Y, Gray C, Vuocolo T, Donaldson L, Broadway M, Tellam R (2005) Lipopolysaccharide and lipoteichoic acid induce different innate immune responses in bovine mammary epithelial cells. Cytokine 31:72-86

18. Wellnitz O, Kerr DE (2004) Cryopreserved bovine mammary cells to model epithelial response to infection. Vet Immunol Immunopathol 101:191-202

19. Mitterhuemer S, Petzl W, Krebs S, Mehne D, Klanner A, Wolf E, Zerbe H, Blum H (2010) Escherichia coli infection induces distinct local and systemic transcriptome responses in the mammary gland. BMC Genomics 11:138

20. Bramley AJ (1976) Variations in the susceptibility of lactating and non-lactating bovine udders to infection when infused with Escherichia coli. J Dairy Res 43:205-211

21. Lahouassa H, Moussay E, Rainard P, Riollet C (2007) Differential cytokine and chemokine responses of bovine mammary epithelial cells to Staphylococcus aureus and Escherichia coli. Cytokine 38:12-21

22. Bougarn S, Cunha P, Gilbert FB, Meurens F, Rainard P (2011) Technical note: Validation of candidate reference genes for normalization of quantitative PCR in bovine mammary epithelial cells responding to inflammatory stimuli. J Dairy Sci 94:2425-2430

23. Rainard $P$, Riollet $C$, Berthon $P$, Cunha P, Fromageau A, Rossignol C, Gilbert FB (2008) The chemokine CXCL3 is responsible for the constitutive chemotactic activity of bovine milk for neutrophils. Mol Immunol 45:4020-4027

24. Rainard P, Cunha P, Bougarn S, Fromageau A, Rossignol C, Gilbert FB, Berthon P (2013) T helper 17-associated cytokines are produced during antigen-specific inflammation in the mammary gland. PLoS One 8:e63471

25. Petzl W, Zerbe H, Gunther J, Yang W, Seyfert HM, Nurnberg G, Schuberth HJ (2008) Escherichia coli, but not Staphylococcus aureus triggers an early increased expression of factors contributing to the innate immune defense in the udder of the cow. Vet Res 39:18

26. Jensen K, Gunther J, Talbot R, Petzl W, Zerbe H, Schuberth HJ, Seyfert HM, Glass EJ (2013) Escherichia coli- and Staphylococcus aureus-induced mastitis differentially modulate transcriptional responses in neighbouring uninfected bovine mammary gland quarters. BMC Genomics 14:36

27. Rainard P, Riollet C (2006) Innate immunity of the bovine mammary gland. Vet Res 37:369-400

28. Gu C, Wu L, Li X (2013) IL-17 family: cytokines, receptors and signaling. Cytokine 64:477-485

29. Song $X$, Qian $Y$ (2013) The activation and regulation of IL-17 receptor mediated signaling. Cytokine 62:175-182

30. Wang Y, Zarlenga DS, Paape MJ, Dahl GE (2002) Recombinant bovine soluble CD14 sensitizes the mammary gland to lipopolysaccharide. Vet Immunol Immunopathol 86:115-124

31. Gaffen SL (2011) Recent advances in the IL-17 cytokine family. Curr Opin Immunol 23:613-619

32. Pantschenko AG, Woodcock-Mitchell J, Bushmich SL, Yang TJ (2000) Establishment and characterization of a caprine mammary epithelial cell line (CMEC). In Vitro Cell Dev Biol Anim 36:26-37

33. Li P, Wilde CJ, Finch LM, Fernig DG, Rudland PS (1999) Identification of cell types in the developing goat mammary gland. Histochem J 31:379-393

34. Schmid E, Schiller DL, Grund C, Stadler J, Franke WW (1983) Tissue type-specific expression of intermediate filament proteins in a cultured epithelial cell line from bovine mammary gland. J Cell Biol 96:37-50

35. Bartek J, Durban EM, Hallowes RC, Taylor-Papadimitriou J (1985) A subclass of luminal epithelial cells in the human mammary gland, defined by antibodies to cytokeratins. J Cell Sci 75:17-33

36. Goldammer T, Zerbe H, Molenaar A, Schuberth HJ, Brunner RM, Kata SR, Seyfert HM (2004) Mastitis increases mammary mRNA abundance of beta-defensin 5, toll-like-receptor 2 (TLR2), and TLR4 but not TLR9 in cattle. Clin Diagn Lab Immunol 11:174-185

37. Yang W, Zerbe H, Petzl W, Brunner RM, Gunther J, Draing C, von Aulock S, Schuberth HJ, Seyfert HM (2008) Bovine TLR2 and TLR4 properly transduce signals from Staphylococcus aureus and E. coli, but $S$. aureus fails to both activate NF-kappaB in mammary epithelial cells and to quickly induce TNFalpha and interleukin-8 (CXCL8) expression in the udder. Mol Immunol 45:1385-1397

38. Bougarn S, Cunha P, Harmache A, Fromageau A, Gilbert FB, Rainard P (2010) Muramyl dipeptide synergizes with Staphylococcus aureus lipoteichoic acid to recruit neutrophils in the mammary gland and to stimulate mammary epithelial cells. Clin Vaccine Immunol 17:1797-1809 
39. Gunther J, Petzl W, Zerbe H, Schuberth HJ, Koczan D, Goetze L, Seyfert HM (2012) Lipopolysaccharide priming enhances expression of effectors of immune defence while decreasing expression of pro-inflammatory cytokines in mammary epithelia cells from cows. BMC Genomics 13:17

40. Mattila T, Frost AJ (1989) Induction by endotoxin of the inflammatory response in the lactating and dry bovine mammary gland. Res Vet Sci 46:238-240

41. Paape MJ, Schultze WD, Desjardins C, Miller RH (1974) Plasma corticosteroid, circulating leukocyte and milk somatic cell responses to Escherichia coli endotoxin-induced mastitis. Proc Soc Exp Biol Med 145:553-559

42. Jain NC (1979) Common mammary pathogens and factors in infection and mastitis. J Dairy Sci 62:128-134

43. Lee JW, Paape MJ, Elsasser TH, Zhao X (2003) Recombinant soluble CD14 reduces severity of intramammary infection by Escherichia coli. Infect Immun 71:4034-4039

44. Metcalfe HJ, La Ragione RM, Smith DG, Werling D (2014) Functional characterisation of bovine TLR5 indicates species-specific recognition of flagellin. Vet Immunol Immunopathol 157:197-205

45. Andoh A, Takaya H, Makino J, Sato H, Bamba S, Araki Y, Hata K, Shimada M, Okuno T, Fujiyama Y, Bamba T (2001) Cooperation of interleukin-17 and interferon- $\gamma$ on chemokine secretion in human fetal intestinal epithelial cells. Clin Exp Immunol 125:56-63

46. LeGrand A, Fermor B, Fink C, Pisetsky DS, Weinberg JB, Vail TP, Guilak F (2001) Interleukin-1, tumor necrosis factor a, and interleukin-17 synergistically up-regulate nitric oxide and prostaglandin E2 production in explants of human osteoarthritic knee menisci. Arthritis Rheum 44:2078-2083

47. Granet C, Miossec P (2004) Combination of the pro-inflammatory cytokines IL-1, TNF- $a$ and IL-17 leads to enhanced expression and additional recruitment of AP-1 family members, Egr-1 and NF-kB in osteoblast-like cells. Cytokine 26:169-177

48. Datta S, Novotny M, Pavicic PG Jr, Zhao C, Herjan T, Hartupee J, Hamilton T (2010) IL-17 regulates CXCL1 mRNA stability via an AUUUA/tristetraprolinindependent sequence. J Immunol 184:1484-1491

49. Hartupee J, Liu C, Novotny M, Sun D, Li X, Hamilton TA (2009) IL-17 signaling for mRNA stabilization does not require TNF receptor-associated factor 6 . J Immunol 182:1660-1666

50. Hartupee J, Liu C, Novotny M, Li X, Hamilton T (2007) IL-17 enhances chemokine gene expression through mRNA stabilization. J Immunol 179:4135-4141

51. Sallusto F, Zielinski CE, Lanzavecchia A (2012) Human Th17 subsets. Eur J Immunol 42:2215-2220

\section{Submit your next manuscript to BioMed Central and take full advantage of:}

- Convenient online submission

- Thorough peer review

- No space constraints or color figure charges

- Immediate publication on acceptance

- Inclusion in PubMed, CAS, Scopus and Google Scholar

- Research which is freely available for redistribution 